\title{
Asistensi Penulisan Artikel Untuk Meningkatkan Kualitas Publikasi Mahasiswa Pgsd Universitas Mataram
}

\author{
${ }^{1}$ Arif Widodo, ${ }^{2}$ Asrin, ${ }^{3}$ Asri Fauzi, ${ }^{4}$ Muhammad Syazali, ${ }^{5}$ Umar, \\ ${ }^{6}$ Muhammad Erfan
}

\author{
1,2,3,4,5,6Program Studi Pendidikan Guru Sekolah Dasar, Universitas Mataram

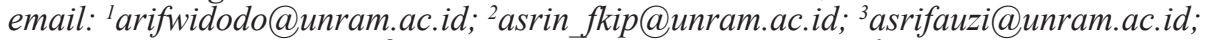 \\ 4muhammadsyazali@unram.ac.id; ${ }^{5}$ umarelmubaraq90@unram.ac.id; ${ }^{6}$ muhammaderfan@unram.ac.id
}

\begin{abstract}
The final output of thesis writing is scientific publication. Based on the analysis of the problem in one of the study programs, it was found that student publications were still oriented to journals that had not been accredited. This community service activity aims to improve the quality of student publications in SINTA accredited scientific journals. This activity was carried out in one of the study programs at the University of Mataram. The participants of the activity are final year students who are compiling articles from the thesis. The method of carrying out activities is through making online publication classes. Through the publication class, students are guided to compose manuscripts, manuscript templates, the introduction of accredited journals, the process of submitting manuscripts to assistance at the manuscript review stage. Based on the results of the program evaluation, it can be concluded that article writing assistance through the publication class is quite successful in improving the quality of student publications. This can be seen from several student publications that have been successfully published in SINTA accredited journals. Barriers experienced during the assistance activities are limited time, the ability of students in the technique of writing articles is still lacking and the motivation to publish in accredited journals is still low. Keywords: student publications, publication class, publication quality
\end{abstract}

\begin{abstract}
Abstrak. Luaran akhir dari penulisan skripsi adalah publikasi ilmiah. Berdasarkan analisis masalah pada salah satu program studi ditemukan fakta bahwa publikasi mahasiswa masih berorientasi pada jurnal yang belum terakreditasi. Kegiatan pengabdian masyarakat ini bertujuan untuk meningkatkan kualitas publikasi mahasiswa ke jurnal ilmiah terakreditasi SINTA. Kegiatan ini dilaksanakan pada salah satu program studi di Universitas Mataram. Peserta kegiatan adalah mahasiswa tingkat akhir yang sedang menyusun artikel dari skripsi. Metode pelaksanaan kegiatan melalui pembuatan kelas publikasi secara online. Melalui kelas publikasi mahasiswa dibimbing untuk menyusun naskah, templating naskah, pengenalan jurnal terakreditasi, proses submit naskah hingga pendampingan pada tahapan review naskah. Berdasarkan hasil evaluasi program dapat disimpulkan bahwa asistensi penulisan artikel melalui kelas publikasi cukup berhasil dalam meningkatkan kualitas publikasi mahasiswa. Hal ini dapat terlihat dari beberapa naskah publikasi mahasiswa yang telah berhasil publish dijurnal terakreditasi SINTA. Hambatan yang dialami selama kegiatan asistensi adalah keterbatasan waktu, kemampuan mahasiswa dalam teknik menulis arikel masih kurang dan motivasi untuk melakukan publikasi di jurnal terakreditasi masih rendah.
\end{abstract}

Kata Kunci. publikasi mahasiswa, kelas publikasi, kualitas publikasi

\section{Pendahuluan}

Menulis merupakan bagian dari literasi dasar yang sangat dibutuhkan pada abad 21. Pengembangan literasi tidak dapat terwujud tanpa adanya aktivitas menulis (Kusmana 2017).
Namun demikian tidak sedikit dari mahasiswa yang belum memiliki kebiasaan menulis dengan baik (Widodo et al. 2020). Terdapat hasil penelitian yang menyebutkan bahwa masih banyak mahasiswa yang mengalami kesulitan dalam menulis ilmiah (Syazali et al. 
2020). Merasa tidak berbakat dan tidak memiliki kompetensi menulis sering menghantui mahasiswa (Rahmiati 2013). Terlebih lagi terkait dengan publikasi artikel ilmiah kemampuan mahasiswa masih perlu ditingkatkan (Sukardi, Burhanuddin, and Wardana 2019). Satusatunya karya mahasiswa hanyalah skripsi. Ironisnya adalah banyak diantara mahasiswa yang masih mengalami kesulitan dalam mengkonversi skripsi menjadi artikel untuk dipublikasikan pada jurnal terakreditasi. Melalui menulis keterampilan mahasiswa dalam memahami informasi dapat meningkat. Dalam sebuah penelitian disebutkan bahwa semakin sering menulis dapat bermanfaat untuk membentuk kejujuran dalam bidang akademik, yaitu mengurangi perilaku plagiat (Nimasari 2017). Kejujuran dalam bidang akademik sangat penting diperhatikan karena muara dari aktivitas menulis adalah publikasi ilmiah (Adhikara et al. 2014).

Publikasi mahasiswa merupakan salah satu aspek yang harus diperhatikan di perguruan tinggi. Hal ini dikarenakan salah satu indikator program studi yang unggul dapat terlihat dari aktivitas publikasi mahasiswa.
Salah satu indikator kualitas publikasi mahasiswa dapat terlihat dari kualitas jurnal untuk publikasi. Besarnya jumlah publikasi mahasiswa pada jurnal yang terakreditasi dapat menunjukkan kualitas dari program studi. Permasalahannya adalah jumlah publikasi mahasiswa masih rendah. Terlebih lagi publikasi pada jurnal ilmiah terakreditasi. Sebagian besar publikasi hanya pada jurnal nasional yang belum terakreditasi. Banyak mahasiswa yang menganggap aktivitas publikasi hanya sekedar syarat untuk mendapatkan kelulusan (Persadha 2016). Terlebih lagi dengan rendahnya standar kelulusan yang hanya cukup pada level jurnal ilmiah tidak terakreditasi membuat mahasiswa kurang serius dalam publikasi. Implikasinya mahasiswa hanya berorientasi pada jurnal yang belum terakreditasi dalam melakukan publikasi.

Kondisi semacam inilah yang dihadapi program studi PGSD Universitas Mataram. Permasalahan yang cukup dilematis. Disatu sisi keterlibatan mahasiswa dalam publikasi ilmiah sangat diharapkan agar visi misi program studi dapat diwujudkan, namun di sisi lain kemampuan mahasiswa dalam publikasi

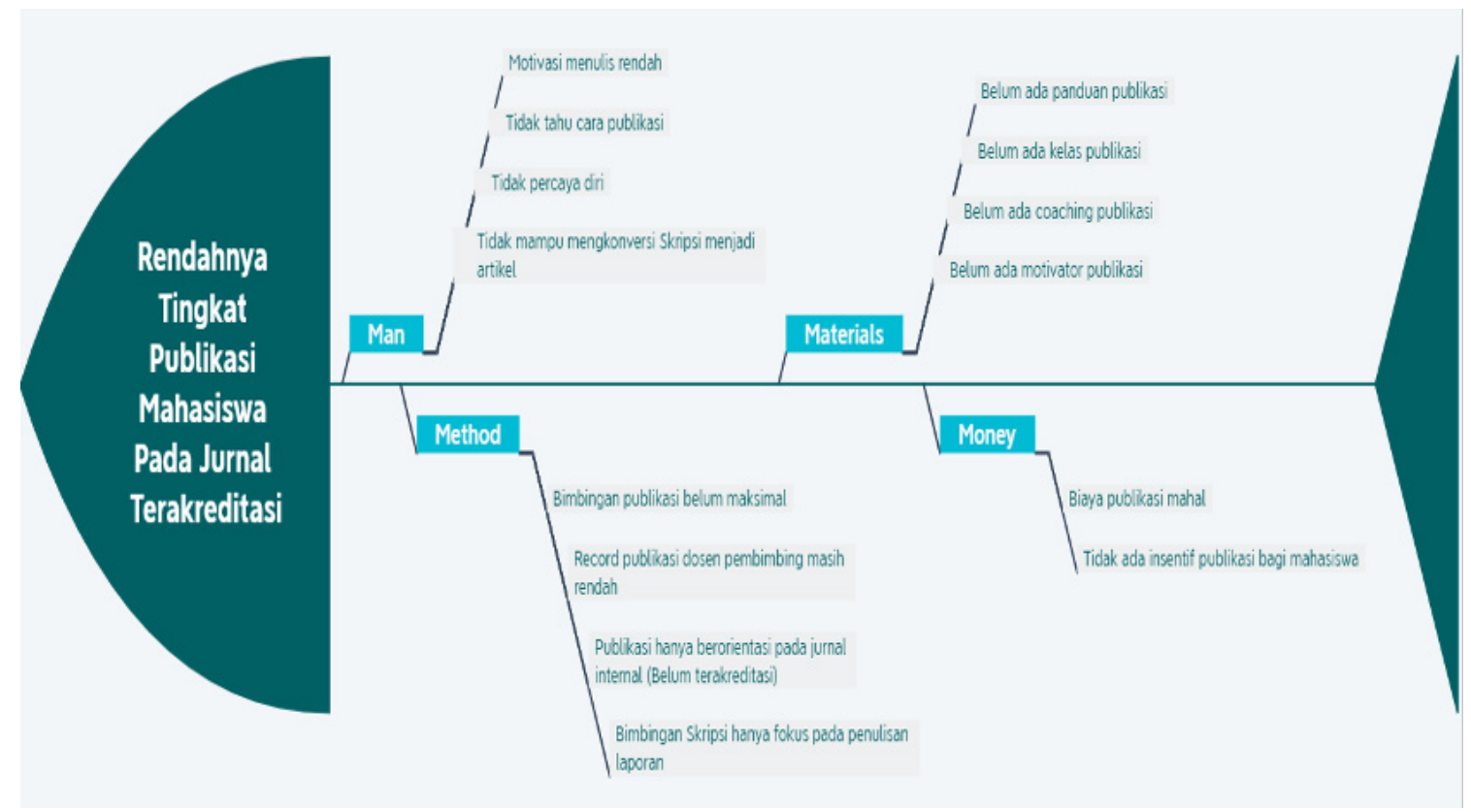

Gambar 1. Fishbhone Analysis 


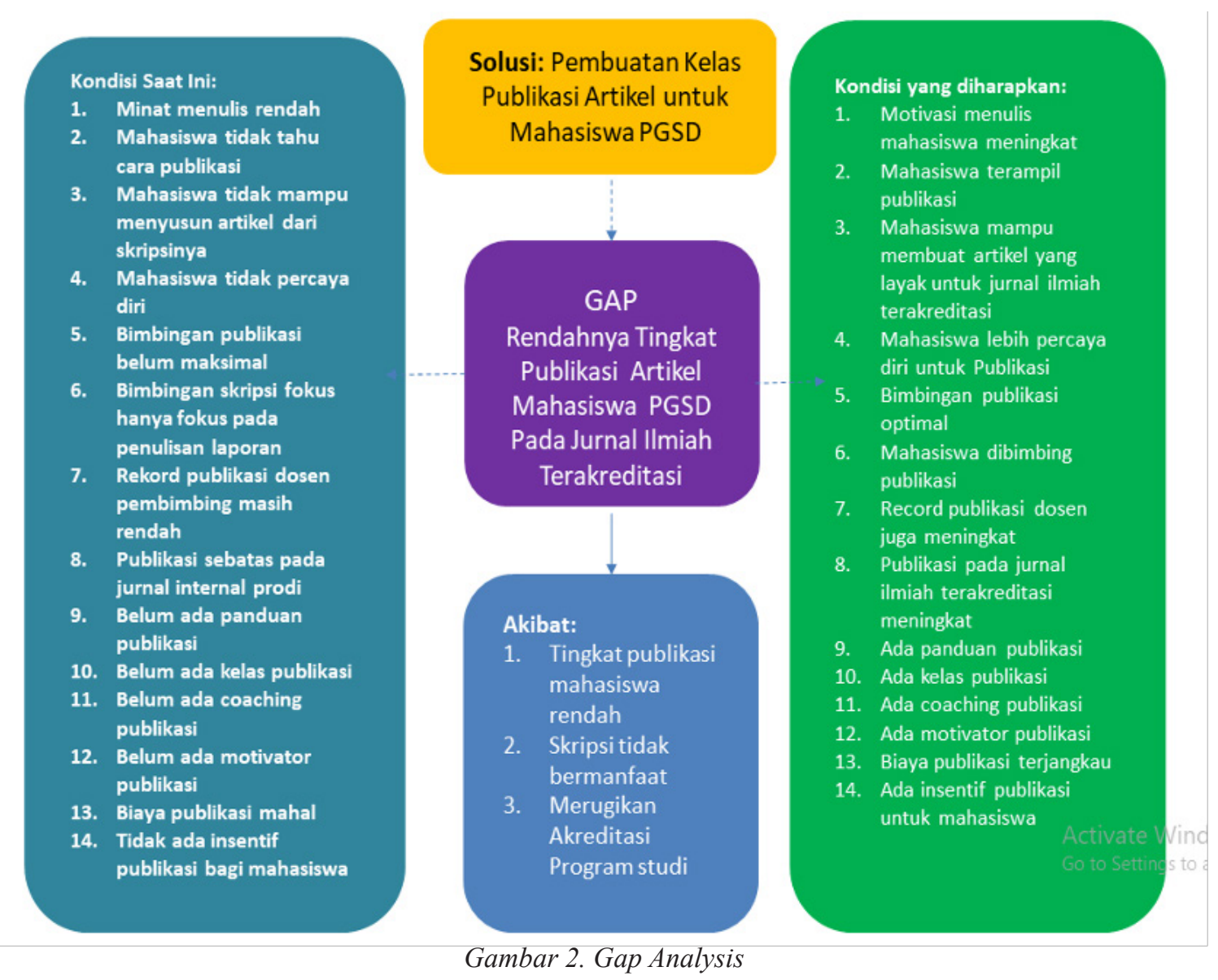

masih rendah. Visi program studi PGSD pada tahun 2025 adalah menjadi Program Studi yang unggul dalam menghasilkan lulusan yang profesional dan berkarakter melalui pendidikan dan pembelajaran berbasis riset. Salah satu cara yang dapat dilakukan untuk mewujudkan visi tersebut adalah dengan meningkatkan publikasi artikel mahasiswa pada jurnal ilmiah terakreditasi. Realitanya adalah jumlah publikasi mahasiswa pada jurnal ilmiah terakreditasi sangat minim.

Salah satu indikator kualitas program studi dapat terlihat dari aktivitas publikasi mahasiswa. Kualitas publikasi mahasiswa dapat terlihat pada level jurnal ilmiah yang dituju. Permasalahannya adalah sebagian besar mahasiswa hanya mampu melakukan publikasi pada jurnal ilmiah tidak terkareditasi. Berdasarkan analisis situasi tersebut perlu dilakukan upaya untuk meningkatkan kualitas publikasi mahasiswa, terutama pada jurnal ilmiah terakreditasi. Solusi yang ditawarkan dalam mengatasi permasalahan tersebut adalah membuat kelas publikasi.

Permasalahan publikasi jika dibiarkan berlarut-larut bukan tidak mungkin visi yang dicanangkan program studi sulit diwujudkan. Diperlukan terobosan dan inovasi agar permasalahan publikasi mahasiswa pada jurnal terakreditasi dapat terselesaikan. Agar solusi yang diberikan tepat sasaran terlebih dahulu harus dianalisis akar permasalahan rendahnya publikasi mahasiswa pada jurnal ilmiah terakreditasi.

Berdasarkan fisbhone analisis terhadap rendahnya tingkat publikasi mahasiswa pada jurnal ilmiah terakreditasi pada gambar 1, maka solusi yang dapat ditawarkan adalah pembuatan kelas publikasi. Melalui kelas publikasi mahasiswa akan dibimbing secara 
intensif mulai dari pembuatan artikel dari skripsi hingga proses submit pada jurnal ilmiah terakreditasi.

Gambar 2 memperlihatkan gap analisis dan solusi yang ditawarkan dalam mengatasi permasalahan. Untuk mempermudah proses publikasi mahasiswa disediakan panduan publikasi agar mahasiswa dapat memahami tata cara publikasi pada jurnal ilmiah terakreditasi. Hal ini perlu dilakukan mengingat pengetahuan dasar tentang OJS di kalangan mahasiswa masih terbatas (Septian et al. 2021). Mahasiswa dituntut untuk memiliki kemampuan dalam mengakses media online sebagai bekal dalam melakukan publikasi (Bahri et al. 2020).

\section{Metode Ilmiah}

Penyelesaian tantangan yang dihadapi program studi dalam meningkatkan kualitas program studi adalah dengan membuat kelas publikasi. Kelas publikasi berisi tentang asistensi penulisan artikel yang akan dipublikasikan pada jurnal terakreditasi. Melalui kegiatan asistensi ini mahasiswa dibimbing untuk menyusun naskah, templating naskah, pengenalan jurnal terakreditasi, proses submit naskah hingga pendampingan pada tahapan review naskah. Prosedur kegiatan dapat divisualisaikan pada gambar 3 .

Berdasarkan Gambar 3 dapat diketahui bahwa prosedur kegiatan diawali dengan regitrasi peserta, pembuatan kelas website publikasi, melakukan sosialisasi, membuat panduan publikasi, bimbingan penulisan artikel, worskhop publikasi, pendampingan publikasi, evaluasi kegiatan dan pembuatan laporan kegiatan.

Metode pelaksanaan kegiatan pengabdian masyarakat ini dilakukan secara online. Penggunaan media online dewasa ini lebih efektif dan efisien dan fleksibel dalam pelaksanaannya. Menurut (Fazriyah, Cartono, and Awangga 2020) Perkembangan teknologi informasi yang pesat harus dapat dimanfaatkan dalam kegiatan pembelajaran.

Secara garis besar pelaksanaan kegiatan dapat dibagi menjadi dua bagian yaitu tahapan teoretik dan praktik. Pada tahapan teoretik aktivitas kelas publikasi berisi tentang pemahaman konsep menulis dan teknik publikasi pada jurnal ilmiah terakreditasi. Pada tahapan praktik aktivitas kelas publikasi lebih banyak berisi tentang praktik publikasi pada jurnal ilmiah terakreditasi. Kedua tahapan ini penting dilakukan agar mahasiswa diakhir kelas dapat memiliki naskah yang telah disubmit pada jurnal

\section{Prosedur Kegiatan}

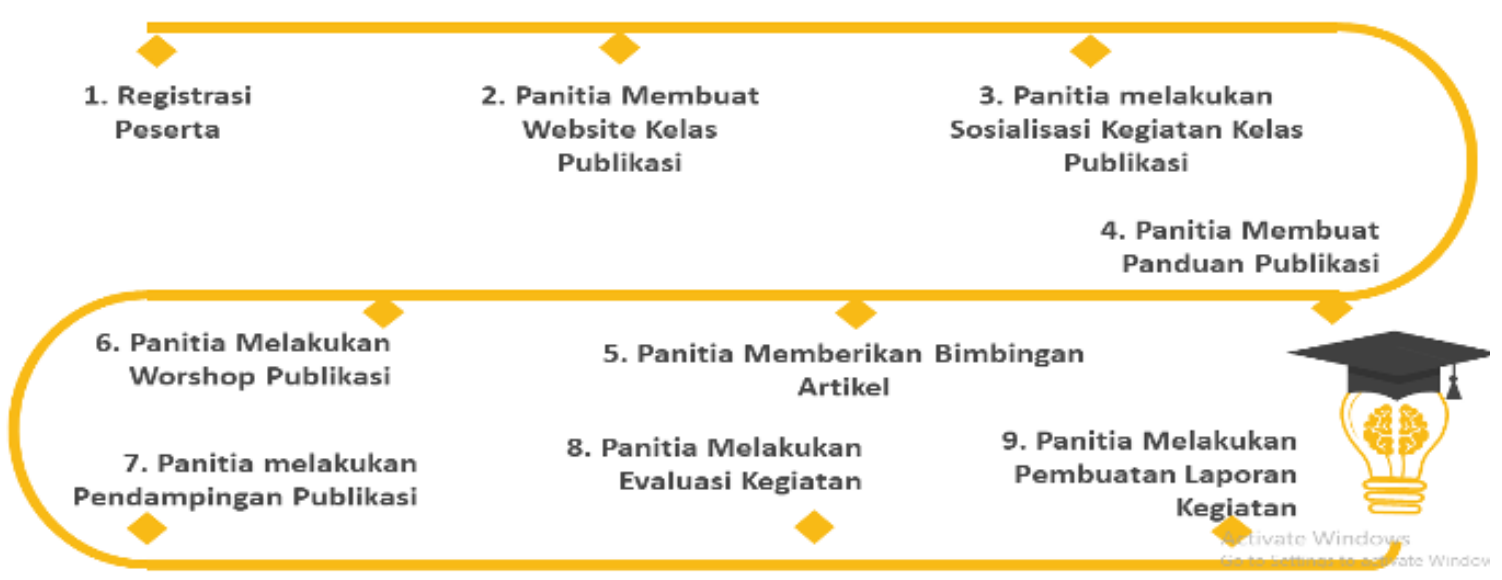

Gambar 3. Prosedur kegiatan 
ilmiah terakreditasi.

\section{Hasil dan Pembahasan}

Kegiatan pengabdian masyarakat ini diikuti oleh 12 mahasiswa tingkat akhir di program studi PGSD Universitas Mataram. Salah satu tujuan yang paling mendasar pada kegiatan pengabdian ini adalah membantu mahasiswa untuk menyelesaikan kewajiban publikasi karena terkendala pandemi. Bimbingan publikasi selama pandemi tidak dapat berjalan maksimal terutama bimbingan artikel ke jurnal ilmiah terakreditasi. Kegiatan inti dalam kelas publikasi adalah sosialisasi, bimbingan, worskshop, dan pendampingan publikasi.

Secara umum tahapan pelaksanaan kegiatan dapat diuraikan sebagai berikut: Pertama, Persiapan kegiatan, melaksanakan diskusi dengan tim pengabdian secara online dan menyusun SOP kegiatan. Kedua, Pembuatan kelas publikasi secara online. Kegiatan yang dilakukan pada tahapan ini adalah membuat website kelas publikasi menggunakan Google Classroom, mengunggah materi publikasi artikel dan memasukkan mahasiswa ke dalam kelas publikasi. Ketiga, Sosialisasi kelas publikasi kepada mahasiswa. Kegiatan sosialisasi kelas publikasi diawali dengan melakukan komunikasi kepada dosen pembimbing skripsi. Salah satu tujuannya adalah menambah peserta yang berminat untuk masuk ke dalam kelas publikasi. Setelah peserta terkumpul kemudian dilakukan pendataan. Tahapan selanjutnya adalah melakukan sosialisasi kepada mahasiswa tentang pentingya publikasi pada jurnal ilmiah terakreditasi. Kegiatan sosialisasi kelas publikasi dilakukan secara tatap muka. Mahasiswa pada kegiatan ini juga diberi pre tes sebagai bahan evaluasi pelaksanaan kegiatan.

Gambar 4 di atas merupakan screenshot kelas publikasi artikel jurnal ilmiah yang dibuat dengan memanfaatkan Google Classroom. Kelas online ini dibuat untuk memudahkan komunikasi dengan mahasiswa yang dibimbing.

Keempat, Pembuatan panduan publikasi. Kegiatan penyusunan panduan publikasi diawali dengan pencarian literatur yang relevan baik di perpustakaan maupun penelusuran secara online. Setelah mendapatkan referensi yang cukup langkah selanjutnya adalah melakukan FGD. Tujuannya adalah mendapatkan saran dan masukan dari seluruh anggota tim. Setelah FGD kemudian dilanjutkan dengan penyusunan panduan publikasi. Dalam penyusunan panduan publikasi anggota tim yang sesuai dengan tugas masingmasing yang telah ditetapkan.

Kelima, Bimbingan penulisan naskah artikel. Tahapan pembimbingan artikel merupakan tahapan terberat dalam kegiatan aktualisasi karena dalam

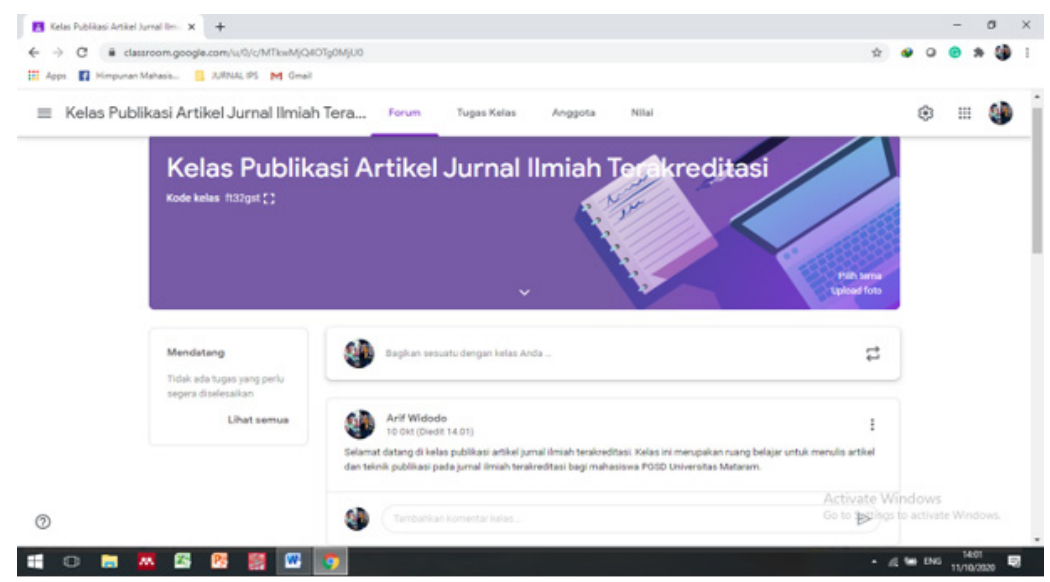

Gambar 4. Kelas Publikasi Menggunakan Google Classroom 
tahapan ini sangat menentukan kualitas naskah artikel yang disubmit pada jurnal ilmiah terakreditasi. Diterima atau ditolaknya artikel sangat dipengaruhi oleh kualitas artikel itu sendiri. Selain itu mahasiswa memiliki kepentingan yang berbeda terhadap artikel. Beberapa mahasiswa membutuhkan artikel segera disubmit sebagai syarat ujian. Maka dari itu, bimbingan penulisan artikel dimulai sejak awal pembukaan kelas hingga pendampingan publikasi.

Bimbingan individual perlu dilakukan kareana ada perbedaan kemampuan mahasiswa dalam menyelesaikan draf artikel. Bimbingan penulisan artikel selain secara tatap muka juga dilakukan secara online. Hal ini dilakukan agar kegiatan bimbingan dapat berjalan lebih efektif dan efisien. Salah satu aspek yang paling mendasar dalam penulisan artikel adalah penggunaan manajer referensi. Maka dari itu dalam tahapan ini mahasiswa diperkenalkan dengan software Mendeley untuk mempermudah dalam penulisan sitasi dan daftar pustaka. Setelah artikel dari skripsi selesai dibuat kemudian mahasiswa diajari melakukan templating artikel sesuai dengan jurnal yang dituju. Keenam, Workshop publikasi ilmiah. Workshop publikasi tidak hanya teoritis, tetapi langsung mengajarkan praktik publikasi. Mahasiswa dibimbing tata cara publikasi pada jurnal terakreditasi. Produk yang dihasilkan dalam kegiatan workshop ini adalah masing-masing mahasiswa telah mempunyai akun register pada jurnal yang dituju. Membuat akun sebelum submit manuskrip adalah tahapan wajib yang harus dilakukan oleh penulis artikel. Agar tidak mengalami masalah dalam pengiriman manuskrip maka akun yang dibuat harus benar-benar valid. Ketujuh, Pendampingan tahapan publikasi. Pendampingan publikasi dilakukan setelah semua tahapan penulisan artikel selesai. Namun dengan berbagai pertimbangan terdapat beberapa mahasiswa yang telah dibimbing untuk sumbit terlebih dahulu. Pendampingan publikasi diawali dengan penyiapan naskah. Setelah naskah dipastikan dengan ketentuan jurnal maka mahasiswa dibimbing untuk submit naskah mulai dari login pada akun register masingmasing, upload manuskrip, enter meta data, upload supplementary dan melihat status naskah yang dikirim.

Setelah naskah selesai disubmit, langkah selanjutnya adalah mengajarkan mahasiswa untuk melihat status manuskrip yang telah di-submit. Langkah selanjutnya adalah kegiatan kedelapan yaitu Evaluasi pelaksanaan kegiatan. Evaluasi kegiatan dilakukan dengan beberapa tahap. Tahap pertama adalah mengukur ketercapaian jumlah manuskrip yang telah di-submit pada jurnal ilmiah terakreditasi. Jumlah manuskrip yang telah di-submit, kemudian ditabulasi berapa jumlah

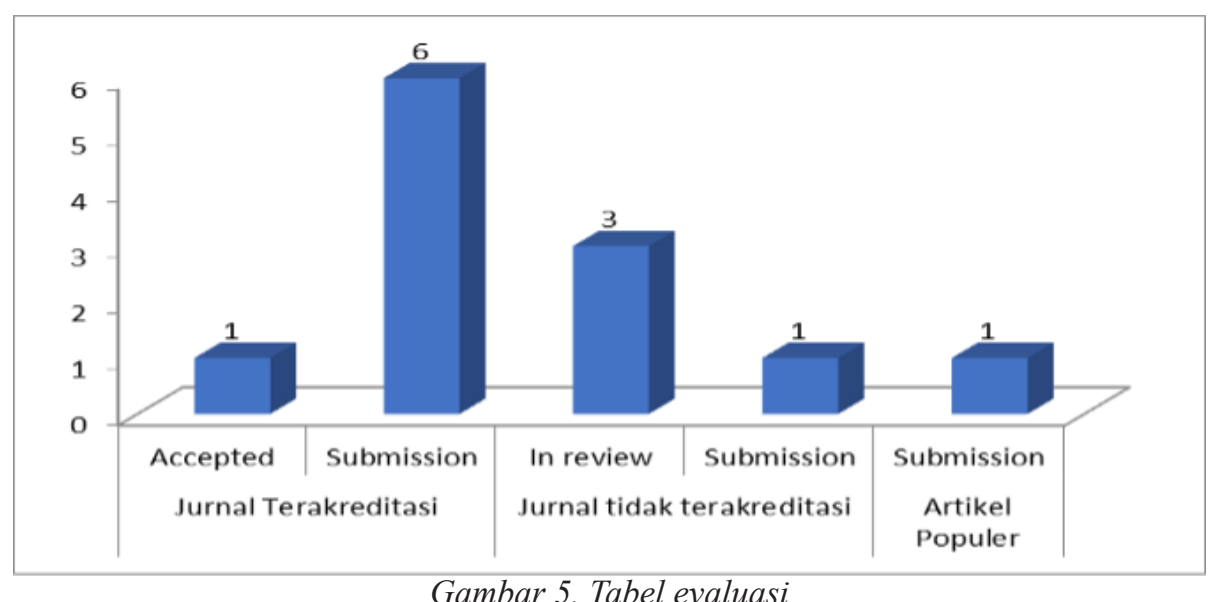

Gambar 5. Tabel evaluasi 
manuskrip yang disubmit pada jurnal ilmiah terakreditasi, jurnal belum terakreditasi maupun artikel populer yang dikirim pada media populer. Tahap kedua, dilakukan survei online terkait dengan kepuasan mahasiswa selama belajar di kelas publikasi.

Berdasarkan Gambar 5 dapat diketahui bahwa jumlah peserta secara keseluruhan adalah 12 mahasiswa. Secara keseluruhan jumlah manuskrip yang telah disubmit pada jurnal ilmiah terakreditasi sejumlah 7 manuskrip. Sebanyak 6 manuskrip berstatus submission atau awaiting assignment dan 1 berstatus accepted (telah mendapat LOA). Jumlah manuskrip yang tersubmit pada jurnal belum terakreditasi sebanyak 4 naskah, dengan 3 naskah berstatus inreview dan 1 naskah berstatus submission. Data ini menunjukkan keberhasilan kegiatan asistensi penulisan artikel bagi mahasiswa. Terdapat satu naskah yang berisi artikel populer sebagai luaran tambahan yang telah dikirim pada media populer (Lombok Pos). Target 5 manuskrip yang disubmit pada jurnal ilmiah terakreditasi telah terpenuhi.

Proses penerbitan artikel pada jurnal ilmiah terakreditasi tidak dapat dilakukan secara instan, perlu proses yang panjang hingga manuskrip dapat diterbitkan. Maka dari itu tim akan terus melakukan pendampingan hingga misi utama meningkatkan jumlah publikasi artikel mahasiswa pada jurnal ilmiah terakreditasi dapat terwujud. Meningkatnya jumlah publikasi mahasiswa dapat memberikan dampak yang baik terhadap reputasi organisasi dalam bidang publikasi, sehingga dapat memberikan sumbangan nyata dalam akreditasi program studi maupun universitas. Selain itu dengan adanya rencana tindak lanjut ini dapat memberikan manfaat yang besar kepada penyusun karena dapat konsisten dalam belajar dan mengawal kegiatan publikasi mahasiswa.

Hambatan yang dihadapi selama pembimbingan artikel adalah mahasiswa ingin segera mengirim naskah sebagai syarat ujian sehingga tidak bersedia disubmit pada jurnal terakreditasi karena khawatir dengan prores review yang panjang. Sedikitnya waktu yang dipersiapkan dalam menulis naskah publikasi berimplikasi terhadap rendahnya kualitas artikel mahasiswa. Sebagian besar mahasiswa beranggapan bahwa tujuan utama dalam penulisan artikel hanya sekedar untuk memenuhi syarat kelulusan. Terlebih lagi dengan tidak adanya bimbingan khusus dalam menulis artikel membuat sebagian besar mahasiswa tidak mengetahui alur penulisan yang benar. Implikasinya mahasiswa hanya copy paste dari skripsi yang telah dibuat. Tidak sedikit mahasiswa merasa kesulitan dalam mengkonversi skripsi menjadi naskah publikasi. Hal ini merupakan problematika serius yang menyebabkan kualitas artikel mahasiswa rendah.

Sebuah karya tidak dapat dikatakan ilmiah jika tidak mengikuti kaidah ilmiah yang telah ditetapkan. Mulai dari metode hingga tata cara penulisan harus diperhatikan dengan cermat. Salah satu hal yang sangat penting untuk dicermati dalam tata tulis adalah penulisan kutipan. Banyak ditemukan mahasiswa yang masih salah dalam mengutip sumber, baik dari buku maupun dari jurnal ilmiah. Bahkan banyak ditemukan naskah yang tidak sesuai antara kutipan dengan daftar pustakanya.

Kesalahan dalam teknik pengutipan merupakan kesalahan mendasar dan dapat berakibat fatal dalam penulisan karya ilmiah. Karya tulis yang tidak sesuai antara kutipan dengan daftar pustaka dapat dikategorikan telah melanggar etika publikasi. Selain salah dalam pengutipan banyak dijumpai mahasiswa yang mengalami kesulitan dalam menulis gaya referensi yang diinginkan jurnal. Hal ini dapat dipahami karena masing-masing jurnal memiliki aturan tersendiri terkait dengan model sitasi 
dan referensi. Dengan adanya berbagai hambatan yang dialami mahasiswa terkait dengan penulisan sitasi dan referensi, perlu dilakukan pengenalan terhadap penggunaan reference manager untuk memudahkan penulisan naskah. Salah satu jenis reference manager yang umum dipakai adalah software Mendeley (Somantri and Sari 2021). Penggunaan reference manager ini harus dimaksimalkan mengingat sangat besar manfaatnya dalam membantu penulisan naskah publikasi mahasiswa. Sejauh ini belum ada mahasiswa yang menggunakan jenis reference manager dalam karya ilmiahnya. Dengan menggunakan reference manager dalam penulisan naskah, konsistensi penulisan referensi dapat terjaga. Selain itu, dengan reference manager dapat mempermudah penulis dalam mengelola sumber pustaka. Terlebih lagi dengan banyaknya sumber pustaka yang disajikan secara online dan memiliki DOI (Digital Object Identifier) membuat penggunaan reference manager sangat bermanfaat. Selain cepat penggunaan reference manager juga dapat meminimalisir kesalahan dalam penulisan sitasi dan referensi (Aisyah and Mahanani 2017).

\section{Kesimpulan dan Saran}

Secara umum pelaksanaan kegiatan pengabdian masyarakat dapat berjalan lancar. Berdasarkan hasil evaluasi kegiatan dapat diketahui bahwa dari 12 peserta kelas publikasi terdapat 7 mahasiswa yang berhasil submit naskah di jurnal ilmiah terakreditasi, sedangkan sisanya sebanyak 5 mahasiswa memilih untuk melakukan publikasi di jurnal tidak terakreditasi dan media populer. Hambatan yang dihadapi selama pembimbingan artikel yang pertama adalah mahasiswa dikejar waktu untuk segera mengirim naskah sebagai syarat ujian sehingga tidak bersedia mengirim naskahnya pada jurnal terakreditasi. Hambatan yang kedua adalah kesiapan dan kelayakan naskah publikasi mahasiswa. Publikasi artikel sebagai salah satu syarat ujian skripsi harus dipersiapkan dengan matang sehingga tidak hanya sekedar publish, tetapi juga harus memperhatikan kualitas jurnal yang dituju. Selain itu motivasi mahasiswa dalam menulis juga harus ditingkatkan, mahasiswa harus dibiasakan untuk menulis dengan baik karena rata-rata mahasiswa hanya memiliki satu karya ilmiah yaitu skripsi. Dengan adanya kelas publikasi artikel diharapkan kuantitas dan kualitas publikasi mahasiswa pada jurnal ilmiah terakreditasi dapat meningkat.

Proses penerbitan artikel dijurnal ilmiah membutuhkan proses yang panjang, maka dari itu disarankan kepada mahasiswa untuk mempersiapkan diri sejak dini terkait dengan naskah yang akan dipublikasikan pada jurnal ilmiah terakreditasi.

\section{DAFTAR PUSTAKA}

Adhikara, MF Arrozi, Sri Handayani, Sapto Jumono, and Darmansyah Darmansyah. 2014. "Pelatihan Penyusunan Artikel Publikasi Ilmiah." Jurnal Pengabdian Masyarakat Abdimas 1(1):41-53.

Aisyah, Eny Nur and Putri Mahanani. 2017. "Pelatihan Menulisan Artikel Ilmiah Bagi Guru Sekolah Dasar Dan Taman Kanak-Kanak Kecamatan Tajinan Kabupaten Malang." Abdimas Pedagogi: Jurnal Ilmiah Pengabdian Kepada Masyarakat 1(1):22-26.

Bahri, Syamsul, Merta Simbolon, Desy Kumala Sari, and Abrahan Laurens Rettob. 2020. "Pelatihan Penggunaan Fasilitas Google Dalam Kegiatan Pembelajaran Untuk Meningkatkan Kompetensi Pedagogik." ETHOS: Jurnal Penelitian Dan Pengabdian Kepada Masyarakat 8(2):205-11.

Fazriyah, Nurul, Cartono Cartono, and Rolly Maulana Awangga. 2020. 
"Pelatihan Aplikasi Pembelajaran

Quizizz Di Sekolah Dasar Kota Bandung." ETHOS: Jurnal Penelitian Dan Pengabdian Kepada Masyarakat 8(2):199-204.

Kusmana, Suherli. 2017. "Pengembangan Literasi Dalam Kurikulum Pendidikan Dasar Dan Menengah." Diglosia - Jurnal Pendidikan, Kebahasaan, Dan Kesusastraan Indonesia 1(1):140-50.

Nimasari, Elok Putri. 2017. "Persepsi Mahasiswa Terhadap Plagiat." Premiere Educandum : Jurnal Pendidikan Dasar Dan Pembelajaran 7(02):115.

Persadha, Dhimas Asih Kusuma. 2016. "Studi Kompetensi Kemampuan Menulis Di Kalangan Mahasiswa." Muaddib: Studi Kependidikan Dan Keislaman 6(1): 1 .

Rahmiati, Rahmiati. 2013. "Problematika Mahasiswa Dalam Menulis Karya Ilmiah." Jurnal Adabiyah 8(2):160-75.

Septian, Ari, Nia Jusniani, Muhammad Husni, and Widyawati Widyawati. 2021. "Penyusunan Artikel Ilmiah Dan Pengenalan Open Journal System (OJS) Bagi Guru-Guru Matematika SMA Di Kabupaten Cianjur." ETHOS: Jurnal Penelitian Dan Pengabdian Kepada Masyarakat 9(1):8-14.

Somantri, Oman and Yeni Priatna Sari. 2021. "Workshop Literasi Digital Menggunakan Reference Manager Pada Masa Pandemi Covid-19." ETHOS: Jurnal Penelitian Dan Pengabdian Kepada Masyarakat 9(2):228-36.

Sukardi, Burhanuddin, and Lalu Ali Wardana. 2019. "Pelatihan Dan Pendampingan Swasunting Artikel Ilmiah Untuk Mahasiswa Magister Bidang Pendidikan Pascasarjana Universitas Mataram." Jurnal Pendidikan Dan Pengabdian Masyarakat 2(1):23-29.

Syazali, Muhammad, I. Ketut Widiade,
Nursaptini Nursaptini, Ni Luh Putu Nina S, and Hasnawati Hasnawati. 2020. "Evaluasi Keterampilan Menulis Makalah Pada Mahasiswa Program Studi Pendidikan Guru Sekolah Dasar." Jurnal Kependidikan: Jurnal Hasil Penelitian Dan Kajian Kepustakaan Di Bidang Pendidikan, Pengajaran Dan Pembelajaran 6(3):546-56.

Widodo, Arif, Abdul Kadir Jailani, Setiani Novitasari, Deni Sutisna, and Muhammad Erfan. 2020. "Analisis Kemampuan Menulis Makalah Mahasiswa Baru PGSD Universitas Mataram." Jurnal DIDIKA : Wahana Ilmiah Pendidikan Dasar VI(1):77-91. 